\title{
Pervasive Developmental Disorder
}

National Cancer Institute

\section{Source}

National Cancer Institute. Pervasive Developmental Disorder. NCI Thesaurus. Code C97179.

A category of developmental disorders characterized by impaired communication and socialization skills. The impairments are incongruent with the individual's developmental level or mental age. These disorders can be associated with general medical or genetic conditions. 